\title{
An empirical model for brand loyalty measurement
}

Received (in revised form): 20th February, 2007

\section{Punniyamoorthy}

has been in academia for over 20 years, teaching in the areas of data analysis, marketing research production and operations management, supply chain management, logistics management, etc. He earned his PhD at Bharathidasan University, India. He acquired a BTech in production technology from the Madras Institute of Technology, Chennai, India, and later obtained an MTech in industrial engineering and operations research from the Indian Institute of Technology, Kharagpur, India. He has published five papers in international journals. One of his papers, 'A strategic decision model for the justification of technology selection' published in the International Journal of Advanced Manufacturing Technology, Vol. 21, pp. 72-78 was selected by the American Society for Mechanical Engineers as one of the best 10 papers in the area of technology selection. He is presently working as a professor in the National Institute of Technology.

\section{Prasanna Mohan Raj}

has experience in the newspaper industry, research and academia. He has published papers on brand architecture and brand loyalty in Indian journals. He teaches marketing research, consumer behaviour and services marketing at the Bharathidasan Institute of Management (BIM), India. He has presented research papers at various international and national conferences, and is also pursuing a PhD in brand loyalty measurement at the National Institute of Technology (NIT), Trichirapalli.

Keywords brand loyalty, perceived value, customer satisfaction, commitment, brand trust, analytical hierarchy process (AHP)

Abstract This study attempts to develop the empirical model for measuring brand loyalty in English newspapers. The model has been developed by using factor analysis, multiple regression analysis and the analytical hierarchy process (AHP) model. It describes the results of a survey of 180 respondents in three dominant cities of India. The work focuses on the factors that influence loyalty. The model has been built based on the factors found which influence loyalty. The study also examines the loyalty behaviour of customers, especially from an Indian perspective, and measures the brand loyalty score of three major English newspapers by using the developed model, concluding with suggestions for mounting high loyalty among customers.

Journal of Targeting, Measurement and Analysis for Marketing (2007) 15, 222-233. doi:10.1057/palgrave.jt.5750044

\section{INTRODUCTION}

While the importance of brand loyalty has been recognised in the marketing literature for at least three decades, the conceptualisation and empirical validation of a brand loyalty model for the newspaper context has not been addressed. This paper describes a theoretical model for investigating the major antecedent influences on loyalty in the newspaper context: involvement,

Correspondence: M. Punniyamoorthy, Department of Management Studies, National Institute of Technology, Tiruchirappalli 620 015, India. Tel: +91431250 0281;

Fax : +91 431250 0133;

E-mail: punniya@nitt.edu perceived value, brand trust, customer satisfaction, commitment and purchase pattern.

Newspapers have always been one of the most important providers of news and entertainment, even though internet and telecommunications are the key sources of information. People have different norms, values and beliefs. When looking for a newspaper, people are interested in those that correspond to their beliefs, they are looking for a newspaper that they can identify themselves with. Consequently, it is important for newspapers to be able to tie customers to them, to deliver something that satisfies the customer, to give the customer an incentive to be loyal. 
The CEO and Chairman of one of the world's leading media research companies, Forrester, said that consumers are going back to reading newspapers and the newspaper industry is ready to respond in accordance with evolving consumer behaviour. ${ }^{1}$ The research conducted by World Association of Newspapers shows that the newspaper industry has more print titles and greater circulation than it had ten years ago, globally. It also added that newspapers in developing countries and emerging markets have been particularly successful - learning from the mistakes of their peers in developed countries and making preemptive moves to claim their territory online. ${ }^{2}$ The World Association of Newspapers claims that newspaper circulations worldwide rose slightly in 2005 while newspaper advertising revenues showed the largest increase in four years. ${ }^{3}$

According to NRS 2006 (the largest survey of its kind in the world), the readership of daily newspapers continues to grow. They have added 12.6 million readers since last year and reach 203.6 million people in India. ${ }^{4}$

The Indian newspaper industry is witnessing high growth. Earlier, newspaper owners thought opportunities lay within their own geographical area. But, in the coming years publishers will be spending over Rs 1,000 crores to invade each other's territories. The newspaper market is bound to grow. New brands are coming into different territories. Newspapers have to identity the factors making the customers loyal to their brands, to defend their market share in this intense competition. Although a great deal of research on loyalty has been extensively carried out on tangible goods, it is suggested that the existing findings in the field of tangible product loyalty cannot be generalised to loyalty for newspapers. Newspapers have distinct attributes from other consumer products. It has very little life-time value. For example, the morning newspaper has sellable value only from early morning to $10 \mathrm{am}$ in one day. Newspapers are sold at less than their manufactured cost, unlike other products. Profit can be made only through advertising revenue, which will be backed by circulation.

This study attempts to measure brand loyalty of customers by identifying the key factors that influence the customers to be loyal to their preferred brands. This study has developed the model for measuring brand loyalty for newspapers by incorporating behavioural and attitudinal attributes. The major objectives of this research study are to find out the factors influencing brand loyalty and to develop the model to measure brand loyalty by incorporating the above factors.

\section{THEORETICAL FOUNDATIONS}

Brand loyalty is a term that researchers and practitioners use to describe a number of phenomena in marketing. ${ }^{5}$ Brand loyalty has had a rich tradition of research in the field and the construct is sometimes identified as having a complex mixture of attitudinal and behavioural elements. ${ }^{6}$ Indeed, brand loyalty might be viewed as a special case of relationship marketing, where the consumer has a significant psychological attachment to the brand entity consumed. ${ }^{7}$ Researchers have started to investigate the relational variables that lie at the heart of a consumer-brand relationship (Chaudhuri and Holbrook $^{8}$ ), which lead to brand loyalty.

Evolution of the conceptualisation and measurement of brand loyalty can be classified into three phases. In earlier days, too much attention had been placed on the earlier history of brand loyalty research on operational measurements with technique-oriented models, emphasising well-defined mathematical models such as Bernoulli, Markov chain or linear learning models. ${ }^{9}$

Researchers and marketers simply defined loyalty as a behaviour of the customer. Thus, repeated purchase in terms of volume and value was alone a significant measurement of customer loyalty until the 1950s. ${ }^{10}$

This one-dimensional measurement model of loyalty concept customer behaviours can be criticised in that the domain of customer loyalty has to conceptually go beyond customers' behavioural measures. Dick and Basu ${ }^{11}$ argue that loyalty should not be regarded as mere repurchase behaviour. This opens the door for a large number of variables that can be examined as the consequences of evaluative constructs in studies of brand loyalty. 
Customer behaviours can be induced by situation factors such as the lack of available alternatives, high switching cost or a tendency towards inertia. ${ }^{12}$

In fact, nearly 75 per cent of customers' purchasing decision is based on their attitude and emotion. $^{13}$

This implies loyalty measurement should include customers' attitudes rather than repeated purchase behavioural pattern only. ${ }^{14}$ But at the same time attitudinal measure is also insufficient for measuring loyalty. Therefore, researchers had measured customer loyalty by incorporating behavioural and attitudinal measures simultaneously. ${ }^{15}$ In this phase of loyalty development, a liking or attitude toward the brand developed, on the basis of cumulatively satisfying usage occasions. The brand loyalty exhibited is directed at the degree of liking for the brand.

Oliver' defines brand loyalty as 'a deeply held commitment to rebuy or repatronise a preferred product/service consistently in the future, thereby causing repetitive same-brand or same brand-set purchasing, despite situational influences and marketing efforts are having the potential to cause switching behavior.' This definition emphasises the two different aspects of brand loyalty: behavioural and attitudinal measures.

Jacoby and Chestnut ${ }^{16}$ provided the preferencebehaviour model for measuring brand loyalty based on these two dimensions: behaviour and attitude.

In the third phase, brand loyalty can be viewed as a 'multidimensional' construct. Several distinct psychological processes determine brand loyalty and it entails multivariate measurements.

Park $^{17}$ argued that attitudinal loyalty and involvement contribute independently to the prediction of different measures of behavioural loyalty.

The path analytical model of relationships between involvement, psychological commitment and loyalty proposed that customers have to go through sequential psychological processes to become loyal participants including (a) the formation of a high level of involvement in purchase, (b) the maintenance of strong attitudes toward resistance to change preferences of the brand and (c) the development of psychological commitment to a brand. ${ }^{18}$

Chaudhuri and Holbrook ${ }^{19}$ suggest that behavioural, or purchase, loyalty consists of repeated purchases of the brand, whereas attitudinal brand loyalty includes a degree of dispositional commitment in terms of some unique value associated with the brand. Following the commitment brand trust acts as a significant factor in influencing brand loyalty. ${ }^{20}$ Brand trust is conceptualised as 'The confident expectations of the brand's reliability and intensions in situations entailing risk to the consumer. ${ }^{21}$ In the consumer-brand domain, this idea implies that the brand is an active relational partner. One way to legitimise the brand as an active member of the relationship rather than a passive object is to highlight ways in which brands are personalised and animated. ${ }^{7}$ It is widely known that perceived value, the potential key determinant of loyalty, is composed of a 'get' component - that is, the benefits a buyer derives from a seller's offering and a 'give' component — that is, the buyer's monetary and nonmonetary costs of acquiring the offering. ${ }^{22}$ Customer satisfaction is the major factor that influences the loyalty behaviour. An increase in the amount of satisfaction goes along with an increase in loyalty. ${ }^{23}$

It has been suggested that loyalty includes some degree of pre-dispositional commitment toward a brand. Commitment is considered as a necessary condition for brand loyalty.

\section{MEASURES OF BRAND LOYALTY OF NEWSPAPERS}

Based on theoretical foundations, this study preliminary identifies the following measures for brand loyalty.

\section{Involvement}

Several studies ${ }^{16,17,24-26}$ have examined the relationship between product involvement and loyalty. LeClerc and Little (1997) found that brand loyalty interacted with product involvement. In a similar vein, Park, ${ }^{17}$ in a study on leisure activities, found that involvement and attitudinal loyalty were highly correlated. Product 
involvement involves an ongoing commitment on the part of the consumer with regard to thoughts, feelings and behavioural response to a product category. ${ }^{27,28}$ Involvement is an unobservable state of motivation, arousal or interest toward a product. Park's ${ }^{17}$ and Kim et al.'s ${ }^{29}$ research provided additional evidence that involvement is closely related to intentions and behaviours, corroborating evidence from numerous studies.

$\mathbf{H}_{1}$ : Higher level of involvement will lead to higher level of brand loyalty.

\section{Perceived value}

The perceived value can be regarded as a 'Consumer's overall assessment of the utility of a product based on perceptions of what is received and what is given'. The assessment denotes comparison of a product's 'get' and 'give' components. ${ }^{30,31}$ Several prior research studies strongly validated the theme that perceived value contributes to customer loyalty (eg Dodds, ${ }^{22}$ Voss, ${ }^{31}$ Parasuraman and Grewal ${ }^{32}$ ). Reichheld ${ }^{33}$ strongly suggested that there is a strong valueloyalty linkage in his work on loyalty.

$\mathbf{H}_{2}$ : Higher level of perceived value will lead to higher level of brand loyalty.

The following four dimensions can be used to describe the Consumer Perceived Value:

\section{Functional value}

The utility derived from the product quality and expected performance of the product is called as functional value. Functional value was seen to be the key influence on consumer choice. Functional value was created by attributes such as reliability, durability.

$\mathbf{H}_{2 \mathbf{a}}$ : Higher level of functional value will lead to higher level of brand loyalty.

\section{Emotional value}

The utility derived from the feelings or affective states that a product generates is called emotional value. Emotions play a part in every purchase decision.
$\mathbf{H}_{\mathbf{2}}$ : Higher level of emotional value will lead to higher level of brand loyalty.

\section{Price-worthiness factor}

The utility derived from the product due to the reduction of its perceived costs.

\section{$\mathbf{H}_{\mathbf{2}}$ : Higher level of price worthiness will} lead to higher level of brand loyalty.

\section{Social value}

The utility derived from the product's ability to enhance social self-concept.

$\mathbf{H}_{\mathbf{2 d}}$ : Higher level of social value will lead to higher level of brand loyalty.

\section{Brand trust}

The relationship between loyalty and brand trust has been explained by Garbarino and Johnson ${ }^{34}$ (amongst other authors) in their work. They highlighted the importance of trust in developing positive and favourable attitudes. Brand trust is the central construct for any long-term relationship. So, in the consumer-brand domain it may be an important contributor to the kind of emotional commitment that leads to long-term loyalty. ${ }^{35}$ So it seems reasonable to expect that the higher the feeling of trust in a brand, the more the consumers are loyal to it.

$\mathbf{H}_{3}$ : Higher level of brand trust will lead to higher level of brand loyalty.

\section{Customer satisfaction}

Customer satisfaction is believed to mediate consumer learning from prior experience and to explain key post-purchase behaviours such as complaining, word of mouth, and repurchase intention and product usage..$^{36}$ Indeed Wang et al..$^{37}$ have suggested that customer satisfaction has a significant influence on repurchase intention and post purchase complaint.

$\mathbf{H}_{4}$ : Higher level of customer satisfaction will lead to higher level of brand loyalty. 


\section{Commitment}

Customer commitment is a central construct in the development and maintenance of marketing relationships because it is a key psychological force that links the consumer to the selling organisation. ${ }^{38}$ The nature of commitment is that it is an attitudinal construct in that it represents customer feelings about the act of maintaining a relationship with a commercial partner (Fullerton). ${ }^{39}$ Commitment likely explains the process by which it is presumed that a customer is loyal because he/she has a favourable attitude toward the brand and is also a frequent buyer of that brand. This process is a feature of brand communities in which consumers share identification with a brand they consume as individuals and as part of the community. ${ }^{40}$ Intuitively, affective commitment would lie at the heart of a consumer-brand relationship because consumers come to be identified with and be involved with many of the brands they regularly consume. $^{7,41}$

$\mathbf{H}_{5}$ : Higher level of commitment will lead to higher level of brand loyalty.

\section{Repeated purchase behaviour}

The consistent repeat purchase is one kind of 'Loyalty-Prone' behaviour, ${ }^{42}$ which forms the base for brand loyalty. Repeated purchase behaviour is an axiomatic term that simply refers to the extent to which consumers re-purchase the same brand in any equal-length period of time. ${ }^{43}$ The strength of behavioural brand loyalty is, therefore, directly a function of the repetitive occurrence of purchase or consumption behaviour. The consumer establishes a systematic biased response or habit simply due to the frequency of encounters. Once the behavioural brand loyalty is strongly manifested by the consumer, it is very difficult to change the systematic bias away from the brand.

$\mathbf{H}_{\mathbf{6}}$ : Repeated purchase pattern will lead to higher level of brand loyalty.

\section{BRAND LOYALTY MEASUREMENT MODEL}

It has been suggested that loyalty is a multidimensional construct. The brand loyalty in this study includes multidimensional constructs including both attitudinal commitment and behavioural purchase loyalty. We propose that involvement, perceived value, trust, customer satisfaction and commitment influence loyalty. The proposed model of brand loyalty for buying English newspaper consists of nine constructs. The constructs and their proposed relations are presented in Figure 1.

Based on the above measures, the regression model can be developed by assuming linear relationship among theses variables.

$$
Y_{i}=b_{0}+b_{1} x_{i 1}+b 2 x_{i 2}+\cdots+b_{m} x_{i m}+e_{i}
$$

where $b_{1}, b_{2} \ldots b_{m}$ are partial regression coefficients. $x_{1}, x_{2} \ldots x_{m}$ are the variables influencing loyalty.

The above regression model denotes the relationship between attributes and loyalty. The relative contribution or influence of each attribute on brand loyalty is measured by

Relative weightage for attribute $A_{j}=b_{j} / \Sigma b_{j}$,

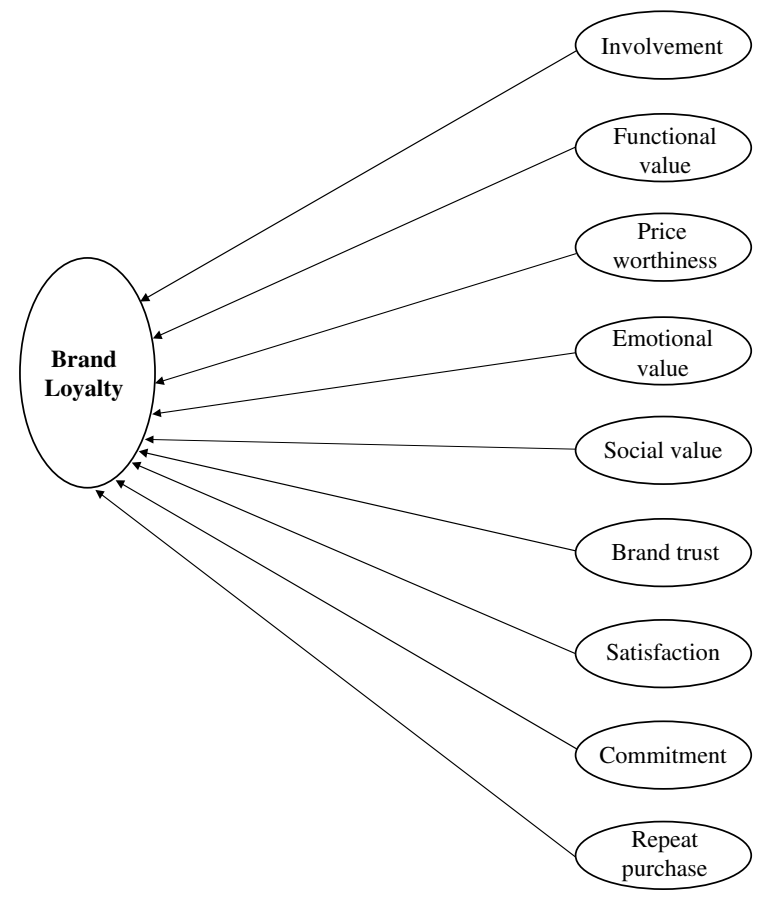

Figure 1: The proposed model for measuring brand loyalty 
where $b_{j}$ is the partial regression coefficient of the ' $j$ 'th attribute and $\Sigma b_{j}$ is the sum of all the partial regression coefficients of the attributes.

The regression equation can be used to develop the model for measuring brand loyalty along with the Analytical hierarchy process (AHP) model. ${ }^{44}$ The AHP model is used to find out the relative weightage of brands. The AHP is a mathematical decision-making technique that allows consideration of both qualitative and quantitative aspects of decisions. It reduces complex decisions to a series of one-on-one comparisons, and then synthesises the results. The relative weightage of brand on each attribute will be calculated by using pairwise comparison matrix of brands with respect to attributes identified for loyalty measurement.

Pairwise comparison matrix for attribute ' $j$ ' for ' $n$ ' number of brands.

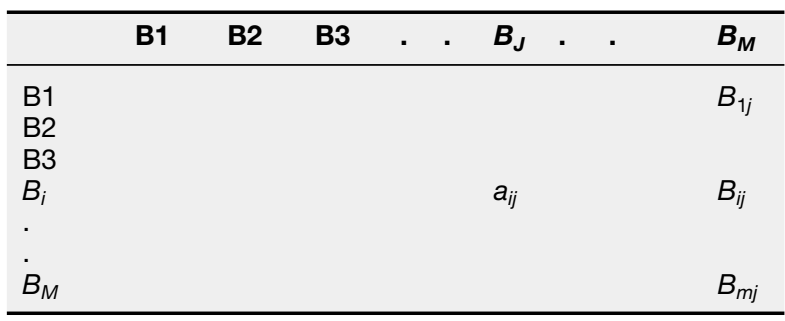

$B_{i j}$ is the relative weightage of brand ' $i$ ' with respect to attribute ' $j$ '; $a_{i j}$ is the value that varies between 1 and 9, when we carry out pairwise comparison between $i \& j$. If the $(i, j)$ cell is a strong cell, then $(j, i)$ becomes a weak cell and it takes the reciprocal value of the $(i, j)$ cell. This matrix is a general matrix for the attribute $j$ and the relative weightage of each brand is arrived at by the AHP.

It denotes the score obtained by brand ' $i$ ' in the attribute of ' $j$ '. Thus the relative weightage of attribute and the relative weightage of brand with respect to attribute are arrived at by using regression and the AHP model. The final model of measuring loyalty will be developed by using the above findings as shown in Figure 2.

Here $B_{i j}$ is the relative weightage of brand ' $i$ ' with respect to attribute ' $j$ '.

The brand loyalty index for a brand $i$,

$$
L_{i}=\sum_{J=1}^{M} A_{j} B_{i j}
$$

$B_{i j}=$ relative weightage for brand $i$ with respect to the $J$ th attribute; $A_{j}=$ relative weightage for the attribute $J$.

\section{RESULTS AND DISCUSSION Measurement assessment}

To ensure the content validity of the scales, the items selected must represent the concept about which generalisations are to be made. Therefore, items selected for the constructs were mainly

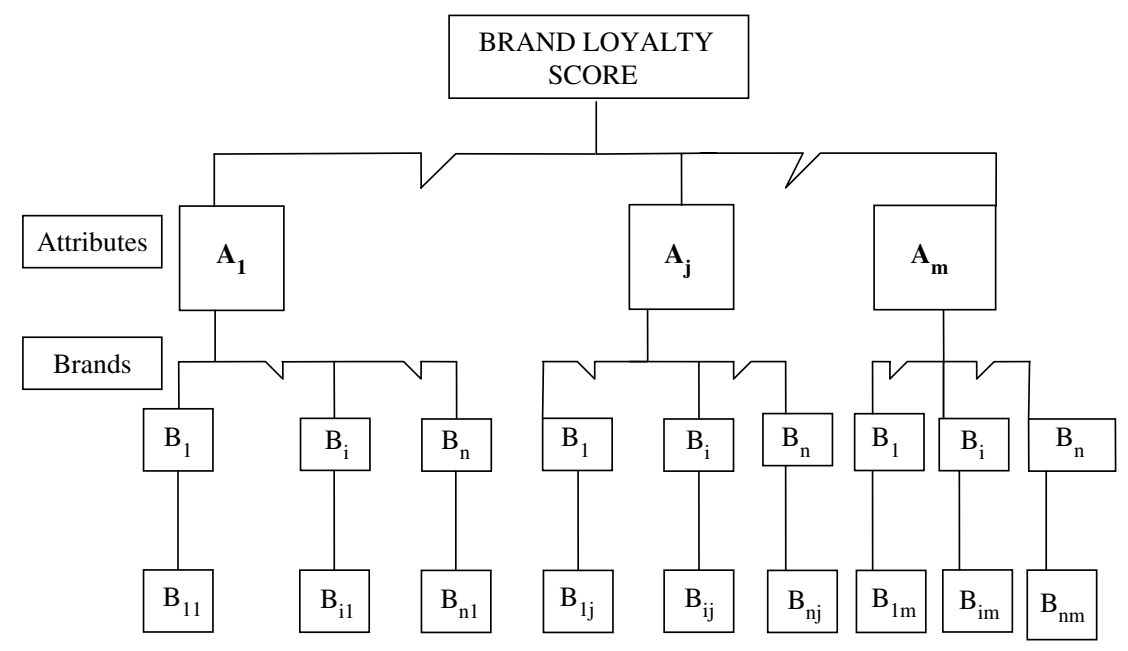

Figure 2: Model for measuring loyalty 
adapted from prior studies to ensure content validity. Construct validity determines the extent to which a scale measures a variable of interest. In this study, Straub's ${ }^{45}$ processes of validating instruments in MIS research in terms of convergent validity and discriminant validity are followed. Thus, a principal components factor analysis with varimax rotation was conducted to investigate the distinctions among customer satisfaction, trust, perceived value, commitment, satisfaction, involvement and loyalty (Table 1).

Perceived value was measured by the 'PERVAL' Consumer Perceived scale developed by Sweeney and Soutar. ${ }^{46}$

Four items for measuring brand trust construct were adapted from Delgado. ${ }^{47}$ The item to measure customer satisfaction was taken from previous measures of the overall level of user satisfaction. Commitment was measured by four items adapted from the Pritchard et al. ${ }^{48}$ 'resistance to change' scales. Table 2 lists the items used in this study.

The methodology was based on the development of a self-administered questionnaire using a convenience sampling. In total, 180 completed surveys were received and all the respondents had responded. Data were collected from the Indian cities of Chennai, Bangalore and Trichy. The data were factor analysed using principal components analysis with varimax rotation.

The nine factors emerged with no crossconstruct loadings above 0.5 , indicating good discriminant validity. The instrument also demonstrated convergent validity with factor loadings exceeding 0.5 for each construct. Consequently, these results confirm that each of the five constructs is unidimensional and factorially distinct and that all items used to operationalise a particular construct is loaded onto a single factor.

Table 1: Factor analysis results: Principal component extraction

\begin{tabular}{|c|c|c|c|c|c|c|c|c|}
\hline $\begin{array}{l}\text { Scale } \\
\text { items }\end{array}$ & $\begin{array}{l}\text { Functional } \\
\text { value }\end{array}$ & $\begin{array}{l}\text { Price } \\
\text { worthiness }\end{array}$ & $\begin{array}{l}\text { Emotional } \\
\text { value }\end{array}$ & $\begin{array}{l}\text { Social } \\
\text { value }\end{array}$ & $\begin{array}{l}\text { Brand } \\
\text { trust }\end{array}$ & Satisfaction & Commitment & $\begin{array}{l}\text { Repeated } \\
\text { purchase }\end{array}$ \\
\hline F1 & 0.954 & & & & & & & \\
\hline $\mathrm{F} 2$ & 0.757 & & & & & & & \\
\hline F3 & 0.971 & & & & & & & \\
\hline F4 & 0.608 & & & & & & & \\
\hline F5 & 0.912 & & & & & & & \\
\hline F6 & 0.781 & & & & & & & \\
\hline F7 & 0.842 & & & & & & & \\
\hline F8 & 0.922 & & & & & & & \\
\hline F9 & 0.712 & & & & & & & \\
\hline PR1 & & 0.940 & & & & & & \\
\hline PR2 & & 0.873 & & & & & & \\
\hline PR3 & & 0.794 & & & & & & \\
\hline EM1 & & & 0.800 & & & & & \\
\hline EM2 & & & 0.630 & & & & & \\
\hline EM3 & & & 0.792 & & & & & \\
\hline SO1 & & & & 0.791 & & & & \\
\hline $\mathrm{SO} 2$ & & & & 0.773 & & & & \\
\hline SO3 & & & & 769 & & & & \\
\hline T1 & & & & & 0.943 & & & \\
\hline T2 & & & & & 0.578 & & & \\
\hline T3 & & & & & 0.853 & & & \\
\hline T4 & & & & & 0.943 & & & \\
\hline SA1 & & & & & & 0.561 & & \\
\hline $\mathrm{CO} 1$ & & & & & & & 0.515 & \\
\hline CO2 & & & & & & & 0.834 & \\
\hline $\mathrm{CO} 3$ & & & & & & & 0.807 & \\
\hline $\mathrm{CO} 4$ & & & & & & & 0.790 & \\
\hline PUR1 & & & & & & & & 0.781 \\
\hline PUR2 & & & & & & & & 0.914 \\
\hline PUR3 & & & & & & & & 0.902 \\
\hline PUR4 & & & & & & & & 0.940 \\
\hline
\end{tabular}

Note: Only loadings greater than 0.500 are shown. 
Table 2: Scale for measuring loyalty

\begin{tabular}{|c|c|}
\hline $\mathrm{F} 1$ & This newspaper is a highly reliable and credible source \\
\hline F2 & It sticks to its rich heritage of consistent quality of news \\
\hline F3 & It has an acceptable standard of print quality make reading easy \\
\hline F4 & I like the design and layout of this newspaper \\
\hline F5 & Variety of supplements coming from this newspaper are very interesting \\
\hline F6 & This newspaper gives me detailed coverage of news \\
\hline F7 & Variety of advertisements coming from this newspaper are very informative \\
\hline F8 & Job opportunity advertisements coming from this newspaper are useful \\
\hline F9 & This newspaper comes with rich and bold editorial and columns \\
\hline PR1 & This newspaper offers value for money \\
\hline PR2 & It is reasonably priced \\
\hline PR3 & It is economical \\
\hline EM1 & It makes me feel good \\
\hline EM2 & It gives me pleasure \\
\hline EM3 & Wherever I see this newspaper, I would read it \\
\hline SO1 & I will consider my newspaper as a status symbol \\
\hline $\mathrm{SO} 2$ & I feel proud of being the reader of this newspaper \\
\hline $\mathrm{SO} 3$ & Reading of this newspaper will improve the way I am perceived \\
\hline T1 & I can say, my newspaper is honest and sincere \\
\hline T2 & I rely on my newspaper \\
\hline T3 & My newspaper never disappoints me \\
\hline T4 & I believe my newspaper meets my expectations \\
\hline SA1 & Overall, in buying this newspaper, I believe that I would be pleased with it \\
\hline CO1 & I have strong preference for this newspaper \\
\hline $\mathrm{CO} 2$ & My preference for this newspaper would not willingly change \\
\hline $\mathrm{CO} 3$ & To change my preference from this newspaper would require major rethinking \\
\hline $\mathrm{CO} 4$ & Even if close friends recommend another newspaper, I would not change my preference \\
\hline PUR1 & I have been buying this newspaper since I started the habit of reading English newspapers \\
\hline PUR2 & I consider myself to be loyal to this newspaper \\
\hline PUR3 & I will recommend this newspaper as worth reading and buying to friends/relatives \\
\hline PUR4 & If I don't get my newspaper in my doorstep, I will search and buy it in stalls \\
\hline
\end{tabular}

Reliability was evaluated by assessing the internal consistency of the items representing each construct using Cronbach's alpha. The reliability of each construct was as follows: Functional Value $=0.93$; price worthiness $=0.92$.

Emotional value $=0.88$; social value $=0.95$; customer satisfaction $=0.70$; brand trust $=0.88$; commitment $=0.84$; repeated Purchase $=0.96$, involvement $=0.87$.

\section{Hypothesis testing}

The hypothesised relationships were tested using the multiple regression analysis of SPSS 11.5 for Windows. The average scores of the items representing each construct were used in the data analysis. The $R^{2}$ was used to assess the model's overall predictive fit. Properties of the causal paths, including standardised path coefficients, $t$ values and variance, explained for each equation in the hypothesised model are presented in Figure 3.

The influence of perceived value (functional value, price worthiness, emotional value and social value), trust, customer satisfaction and repeated purchase commitment on loyalty has been proved by hypotheses $\mathrm{H}_{1}, \mathrm{H}_{2 \mathrm{a}}, \mathrm{H}_{2 \mathrm{~b}}, \mathrm{H}_{2 \mathrm{c}}, \mathrm{H}_{2 \mathrm{~d}}, \mathrm{H}_{3}, \mathrm{H}_{4}, \mathrm{H}_{5}$ and $\mathrm{H}_{6}$.

As expected, repeated purchase $(b=0.769$, $t$-value $=7.159, p<0.001)$ and functional value $(b=0.138, t$-value $=6.312, p<0.001)$ have relatively strongest influence on loyalty, followed by commitment $(b=0.127, t$-value $=1.484$, $p=0.148)$ and emotional value $(b=0.108$, $t$-value $=1.800, p=0.082)$. Brand trust $(b=0.095$, $t$-value $=2.150, p<0.05)$, price worthiness $(b=0.046, t$-value $=0.778, p=0.443)$, customer satisfaction $(b=0.034, t$ value $=1.523, p=0.138)$ and social value $(b=0.026, t$-value $=1.207$, $p=0.237)$ have a significant positive effect on loyalty. Customers' involvement $(b=0.057$, $t$-value $=2.622, p<0.05)$ also has a significant influence on loyalty.

Therefore, hypotheses $\mathrm{H}_{1}, \mathrm{H}_{2 \mathrm{a}}, \mathrm{H}_{2 \mathrm{~b}}, \mathrm{H}_{2 \mathrm{c}}, \mathrm{H}_{2 \mathrm{~d}}$, $\mathrm{H}_{3}, \mathrm{H}_{4}, \mathrm{H}_{5}$ and $\mathrm{H}_{6}$ are supported. So the proposed model explained a significant percentage of variance in loyalty $\left(R^{2}=98.6\right.$ per cent, $\mathrm{F}$ value $=236.175, p<0.001)$. 


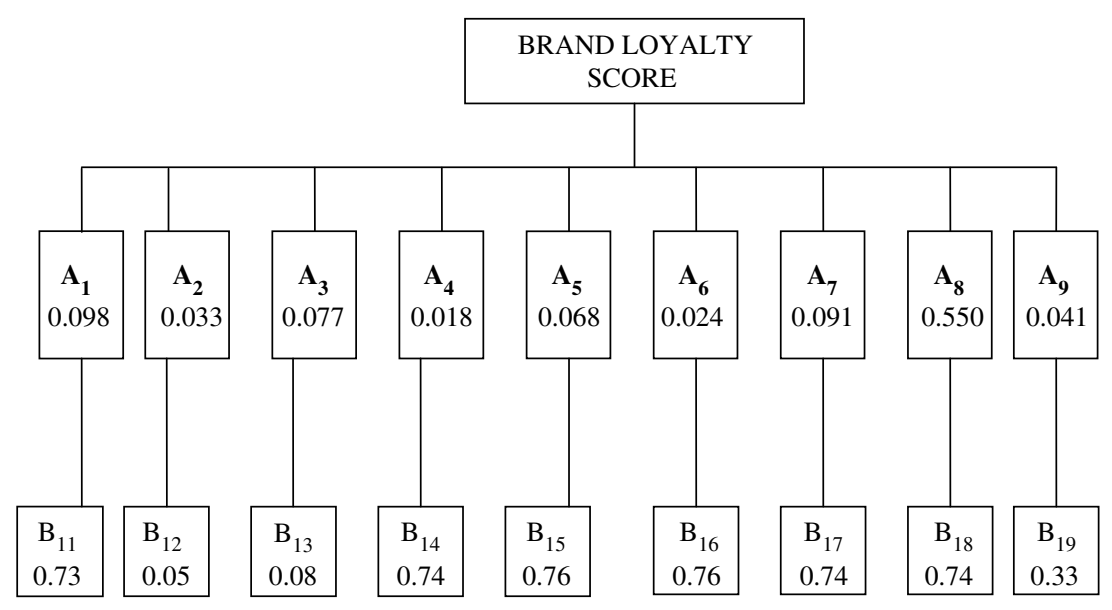

Figure 3: Hypothesis testing results

\section{MANAGERIAL IMPLICATIONS}

This study investigated the direct effects of involvement, perceived value (integration of functional value, price worthiness, emotional value and social value), brand trust, satisfaction, commitment and repeated purchase on loyalty. Integrating these perspectives and empirically examining the factors that build brand loyalty in newspapers advanced our understanding of these constructs. The result suggests that repeated purchase has the strongest influence on loyalty followed by functional value. As suggested by this proposed model, commitment plays a crucial role in building brand loyalty followed by emotional value and brand trust. Interestingly, the priceworthiness factor has less influence on brand loyalty than above-mentioned factors. Therefore, management attention might more fruitfully focus on the development of internal psychological processes such as commitment, emotional value. Building strong perceived value in the minds of customer is forming the foundation for brand loyalty. Brands should develop trust among the customers.

As per the proposed model, nine variables are found to have an influencing power on loyalty.

So the brand loyalty index

$$
L_{i}=\sum_{J=1}^{9} A_{j} B_{l j}
$$

The above equation can be written as follows:

$$
\begin{aligned}
L_{1}= & A_{1} B_{11}+A_{2} B_{12}+A_{3} B_{13}+A_{4} B_{14}+A_{5} B_{15} \\
& +A_{6} B_{16}+A_{7} B_{17}+A_{8} B_{18}+A_{9} B_{19}
\end{aligned}
$$

$B_{19}$ is the relative weightage for brand 1 with respect to the 9 th attribute; $A_{9}$ is the relative weightage for attribute 9 .

\section{Calculation of attribute's relative weightage $\left(A_{j}\right)$}

The regression equation comprises nine attributes,

$$
\begin{aligned}
Y_{i}= & b_{0}+b_{1} x_{1}+b_{2} x_{2}+b_{3} x_{3}+b_{3} x_{3}+b_{4} x_{4} \\
& +b_{5} x_{5}+b_{6} x_{6}+b_{7} x_{7}+b_{8} x_{8}+b_{9} x_{9}
\end{aligned}
$$

where $b_{1}, b_{2} \ldots b_{9}$ are partial regression coefficients.

$X_{1}$ is the functional value; $X_{2}$ is the price worthiness; $X_{3}$ is the emotional value; $X_{4}$ is the social value; $X_{5}$ is the brand trust; $X_{6}$ is the satisfaction; $X_{7}$ is the commitment; $X_{8}$ is the repeated purchase; $X_{9}$ is the involvement.

$$
\begin{aligned}
Y i= & b_{0}+b_{1} 0.138+b_{2} 0.046+b_{3} 0.108 \\
& +b_{4} 0.026+b_{5} 0.095+b_{6} 0.034+b_{7} 0.127 \\
& +b_{8} 0.769++b_{9} 0.057
\end{aligned}
$$

The relative weightage of functional value $=0.138 / 1.4=0.098$.

Similarly, relative weightage scores for all attributes are found and the brand loyalty index for any brand can be calculated by substituting the relative scores of the nine attributes in the 


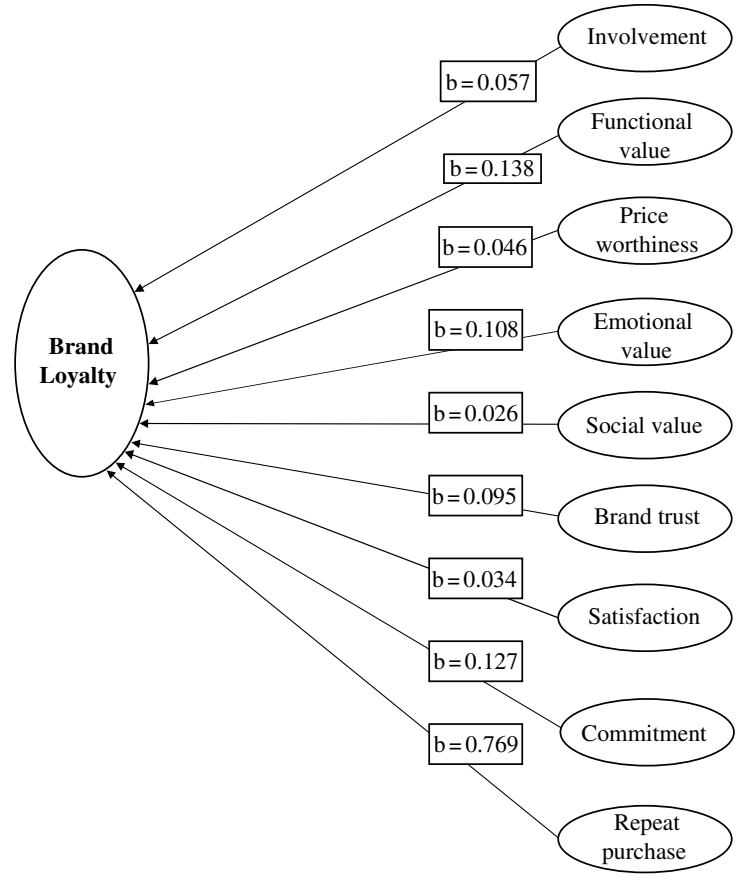

Figure 4: Measurement of brand loyalty index for a brand 'The Hindu'

following equation:

Loyalty Index $=0.098 B_{11}+0.033 B_{12}$

$$
\begin{aligned}
& +0.077 B_{13}+0.018 B_{14} \\
& +0.068+B_{15}+0.024 B_{16}+0.091 B_{17} \\
& +0.550 B_{18}+0.041 B_{19}
\end{aligned}
$$

The final brand loyalty scores will be calculated by substituting their relative weightage in the above equation. The relative weightage of a brand with respect to the attributes are calculated by using the AHP model. Three Indian English newspaper brands are taken for study and their loyalty is measured by using the above loyalty index. The brand loyalty score of the brand 'The Hindu' is calculated by substituting their scores on the nine attributes in the above equation

\section{The Hindu brand}

$$
\begin{aligned}
\text { Loyalty }= & 0.098(0.73)+0.033(0.05)+0.077(0.08) \\
& +0.018(0.74)+0.068(0.76)+0.024(0.76) \\
& +0.091(0.74)+0.550(0.74) \\
& +0.041(0.33)=0.6501
\end{aligned}
$$

The Hindu enjoys 65.01 per cent brand loyalty. Similarly, brand loyalty score is calculated for other two brands The New Indian Express and Deccan Chronicle.
Figure 4 illustrates the above measurement of brand loyalty index for a brand The Hindu.

Similarly, loyalty index can be calculated for all other brands.

\section{Deccan Chronicle brand}

$$
\begin{aligned}
0.098(0.2) & +0.033(0.73)+0.077(0.71) \\
& +0.018(0.19)+0.068(0.05) \\
& +0.024(0.18)+0.091(0.21) \\
& +0.550(0.21)+0.041(0.33) \\
& =0.2985=29.85 \%
\end{aligned}
$$

Deccan Chronicle is placed in the second position by scoring 29.85 per cent brand loyalty.

\section{The New Indian Express brand}

$$
\begin{aligned}
0.098(0.06) & +0.033(0.21)+0.077(0.21) \\
& +0.018(0.07)+0.068(0.19) \\
& +0.024(0.06)+0.091(0.05) \\
& +0.550(0.05)+0.041(0.33) \\
& =0.1309=13.09 \%
\end{aligned}
$$

The New Indian Express is placed in the third position by scoring 13.09 per cent brand loyalty.

In the above examples, 'The Hindu' brand has the highest brand loyalty score as it scored high on the attributes that have high influences on loyalty. For example, The Hindu brand scored high on the attributes of repeated purchase behaviour (0.74) and functional value (0.73), which makes The Hindu brand have high brand loyalty.

In contrast, though Deccan Chronicle brand scored high in the price-worthiness factor (0.73), it has created less impact on loyalty as the priceworthiness factor has little impact on loyalty (0.033).

Both Deccan Chronicle and The New Indian Express brands should score high on the attribute of repeated purchase behaviour. They could increase the repeated purchase by implementing customer franchise sales promotion programmes. Both brands can devise a special loyalty programme for annual subscribers linked with benefits of offering free insurance scheme along with the subscription. The Hindu scores less in emotional value (0.08) when compared to other brands, sending alarm signals to the management. So, if The Hindu brand wants to be a market 
leader, it should develop emotional bondage with customers to retain its market position.

\section{CONCLUSION}

Developing and sustaining the brand loyalty is the biggest challenge in the relentless competition market. Brand loyalty is a multidimensional construct. After having strong theoretical foundation this study has developed model for measuring brand loyalty including multidimensional constructs both attitudinal commitment and behavioural purchase loyalty. The model proposed that involvement, perceived value, trust, customer satisfaction and commitment are having influencing power on the loyalty. Relative weightage of the above attributes were mainly given importance in determining the loyalty score.

\section{References}

1 http://www.wan-press.org/ce/previous/2001/congress.forum/ congress/balding.html.

2 http://www.wan-press.org/IMG/pdf/Pages_de_SFN5.4Editorial Concepts_light.pdf.

3 http://www.newswatch.in/?p=4993.

4 http://www.hindu.com/2006/08/30/stories/2006083010621300. htm.

5 Oliver, R. L. (1999) 'Whence consumer loyalty', Journal of Marketing, Vol. 63, pp. 33-44.

6 Jacoby, J. and Kyner, D. B. (1973) 'Brand loyalty vs repeat purchasing behaviour', Journal of Marketing Research, Vol. 10, No. 1, pp. 1-9.

7 Fournier, S. (1998) 'Consumers and their brands: Developing relationship theory in consumer research', Journal of Consumer Research March, Vol. 24, pp. 343-373.

8 Chaudhuri, A. and Holbrook, M. (2002) 'Product class effects on brand commitment and brand outcomes: The role of brand trust and brand affect', Journal of Brand Management, Vol. 10, No. 1, pp. 33-58.

9 Jagdish, N., Sheth, C. and Whan, P. (1974) 'A theory of multidimensional brand loyalty', Advances in Consumer Research, Vol. 1, pp. 449-459.

10 Lu Ting Pong, J. and Tang Pui Yee, E. (2001) 'An integrated model of service loyalty', Academy of Business \& Administrative Sciences 2001 International Conferences, Brussels, Belgium held on 23rd-25th July, 2001.

11 Dick, A. S. and Basu, K. (1994) 'Customer loyalty: Toward an integrated conceptual framework', Journal of Academy of Marketing Science, Vol. 22, No. 2, pp. 99-113.

12 Cooper, W. H. and Withey, M. J. (1989) 'Predicting exit, voice loyalty, and neglect', Administrative Science Quarterly, Vol. 34, pp. $12-14$.

13 Gremler, D. D. and Brown, S. W. (1996) 'Service loyalty: Its nature, importance and implications', Advancing Service Quality — A Global Perspective, International Service Quality Association Inc., pp. 171-175.
14 Andreassen, T. W. and Lindestad, B. (1998) 'Customer loyalty and complex services', International Journal of Service Industry Management, Vol. 9, No. 1, pp. 7-23.

15 Hallowell, R. (1996) 'The relationships of customer satisfaction, customer loyalty, and profitability: An empirical study', International Journal of Service Industry Management, Vol. 7, No. 4, pp. 27-42.

16 Jacoby, J. and Chestnut, R. W (1978) 'Brand Loyalty Measurement and Management', Wiley, New York, pp. 45-57.

17 Park, S. H. (1996) 'Relationships between involvement and attitudinal loyalty constructs in adult fitness programs', Journal of Leisure Research, Vol. 28, No. 4, pp. 233-250.

18 Iwasaki, Y. and Havitz, M. (1998) 'A path analytical model of the relationships between involvement, psychological commitment and loyalty', Journal of Leisure Research, Vol. 30, pp. 256-280.

19 Chaudhuri, A. and Holbrook, M. B. (2001) 'The chain of effects from brand trust and brand affect to brand performance: The role of brand loyalty', Journal of Marketing, Vol. 65, No. 2, pp. 81-93.

20 Ramesh, K. S. and Advani, J. Y. (2005) 'Factors affecting brand loyalty: A study in an emerging market in fast moving consumer goods', Journal of Customer Behaviour, Vol. 4, No. 2 , pp. 251-275.

21 Andaleeb, S. S. (1992) 'The trust concept: Research issues for channels of distribution', Research in Marketing, Vol. 11, pp. 1-34.

22 Dodds, W. B., Monroe, K. B. and Grewal, D. (1991) 'Effects of price, brand, and store information on buyers' product evaluations', Journal of Marketing Research, Vol. 28, No. 3, pp. 307-319.

23 Bloemer, J. M. M. and Kasper, H. D. P. (1995) 'The complex relationship between consumer satisfaction and brand loyalty', Journal of Economic Psychology, Vol. 16, pp. 311-329.

24 Traylor, M. B. (1981) 'Product involvement and brand commitment: not necessarily the same', Journal of Advertising Research, Vol. 21, pp. 51-56.

25 Traylor, M. B. (1983) 'Ego involvement and brand commitment: not necessarily the same', Journal of Consumer Marketing, Vol. 1, pp. 75-79.

26 Leclerc, F. and John D.C, . Little (1997) 'Can advertising copy make FSI coupons more effective?' Journal of marketing Research, Vol. 34, No. 4, pp. 473-484.

27 Miller, D. W. and Marks, L. J. (1996) 'The moderating effects of enduring involvement on imagery-evoking advertisements', American Marketing Association, pp. 121-128.

28 Gordon, M. E., McKeage, K. and Fox, M. A. (1998) 'Relationship marketing effectiveness: the role of involvement', Psychology and Marketing, Vol. 15, No. 5, pp. 443-459.

29 Kim, S. S., Scott, D. and Crompton, J. L. (1997) 'An exploration of the relationships among social psychological involvement, behavioral involvement, commitment and future intentions in the context of bird watching', Journal of Leisure Research, Vol. 23, pp. 320-341.

30 Zeithaml, V. A. (1988) 'Consumer perceptions of price, quality and value: A means-end model and synthesis of evidence', Journal of Marketing, Vol. 52(July), pp. 2-22.

31 Voss, G. B., Parasuraman, A. and Grewal, D. (1998) 'The roles of price, performance and expectations in determining satisfaction in service exchanges', Journal of Marketing, Vol. 62, No. 4, pp. $46-61$.

32 Parasuraman, A. and Grewal, D. (2000) 'The impact of technology on the quality-value-loyalty chain: A research 
agenda', Journal of the Academy of Marketing Science, Vol. 28, No. 1, pp. 168-174.

33 Reichheld, F. F. (1996) 'Learning from customer defections', Harvard Business Review, Vol. 74, No. 2, pp. 56-67.

34 Garbarino, E. and Johnson, M. S. (1999) 'The different roles of satisfaction,trust and commitment in customer relationships', Journal of Marketing, Vol. 63(April), pp. 70-87.

35 Hess, J. S. (1995) 'Construction and assessment of a scale to measure consumer trust', in Stern B., Zinkhan, G. (eds), 'Proceedings of the American Marketing Association Educators' Conference', Vol. 6, American Marketing Association, Chicago, pp. 20-26.

36 Westbrook, R. A. and Oliver, R. P. (1991) 'The dimensionality of consumption emotion patterns and consumer satisfaction', Journal of consumer Research, Vol. 18, No. 1, pp. 84-91.

37 Wang, S., Tang, T. -I. and Tang, J. T. E. (2001) 'An instrument for measuring customer satisfaction toward web sites that market digital products and services', Journal of Electronic Commerce Research, Vol. 2, No. 3, pp. 89-102.

38 Bansal, H., Irving, G. and Taylor, S. (2004) 'A three-component model of customer commitment to service providers', Journal of the Academy of Marketing Science, Vol. 32, No. 3, pp. 234-250.

39 Gordon, F. (2003) 'When does commitment lead to loyalty?' Journal of Service Research, Vol. 5, No. 4, pp. 333-344.
40 McAlexander, J. H., Schouten, J. W. and Koenig, H. F. (2002) 'Building brand community', Journal of Marketing, Vol. 66, No. 1, pp. $38-51$.

41 Susan, F. (1998) 'Consumers and their brands: Developing relationship theory in consumer research', Journal of Consumer Research, Vol. 24, pp. 343-348.

42 Cunningham, R. M. (1956) 'Brand loyalty - What, pp. 116-138.

43 Ehrenberg, A. S. C. (1988) 'Repeat-Buying Facts, Theory and Applications', Charles Griffin, London, pp. 24-34.

44 Saaty, T. L. (1994) 'Theory and methodology: Highlights and critical points in the theory and application of AHP', European Journal of Operational Research, Vol. 74, pp. 426-447.

45 Straub, D. W. (1989) 'Validating instruments in MIS research', MIS Quarterly, Vol. 13, No. 2, pp. 147-169.

46 Sweeney, J. C. and Soutar, G. N. (2001) 'Consumer perceived value: The development of multiple item scale', Journal of Retailing, Vol. 77, No. 2, pp. 203-220.

47 Delgado, B. E. (2003) 'Development and validation of a brand trust scale', International Journal of Market Research, Vol. 45, No. 1, pp. 35-54.

48 Pritchard, M. P., Havitz, M. E. and Howard, D. R. (1999 'Analyzing the commitment-loyalty link in service contexts', Journal of the Academy of Marketing Science, Vol. 27, No. 3, pp. 333-348. 